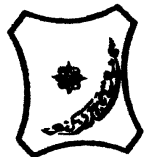

Bayero Journal of Pure and Applied Sciences, 5(1): 103 - 108

Received: January 2012

Accepted: May 2012

ISSN $2006-6996$

\title{
ASSESSMENT OF HEAVY METALS CONCENTRATIONS IN THE SURFACE WATER OF BOMPAI-JAKARA DRAINAGE BASIN, KANO STATE, NORTHERN NIGERIA
}

Imam, T. S.

Department of Applied Biology, Bayero University, Kano, PMB 3011, Kano State, Nigeria

tsimam2001@yahoo.com; GSM: 08133382652

\begin{abstract}
This work aimed at assessing the concentrations of heavy metals in the surface water of BompaiJakara drainage basin. The points of sampling were designated as $A, B, C, D, E$, and $F$. Acid-washed (1L) plastic bottles were used in collecting the water samples, which were then digested using nitric acid ( $\left.\mathrm{HNO}_{3}\right)$. The digested samples were analyzed for $\mathrm{Fe}, \mathrm{Cr}, \mathrm{Cu}, \mathrm{Zn}$ and $\mathrm{Pb}$ using Atomic Absorption Spectrophotometer (Model IL250). The seasonal sequence of heavy metals concentrations showed $\mathrm{Zn}>\mathrm{Fe}>\mathrm{Cr}>\mathrm{Cu}>\mathrm{Pb}$ and $\mathrm{Fe}>\mathrm{Zn}>\mathrm{Cr}>\mathrm{Cu}>\mathrm{Pb}$ in dry and wet seasons respectively, while that of annual was $\mathrm{Cr}>\mathrm{Fe}>\mathrm{Zn}>\mathrm{Cu}>\mathrm{Pb}$. The results showed that all of the five elements analyzed have concentrations well above the FEPA, WHO, AWWA, CCME standard limit for effluents discharge into surface. There was an observed seasonal variations in which dry season had a relatively higher heavy metals concentration, but not statistically significant at $P \leq 0.05$. This study underscores the need for the government to establish water catchments management agency for the purpose of protecting the basin ecologically and health wise, bearing in mind the socio-economic potentialities the basin has on the populace utilizing it and the nation in general. Keywords: Heavy metals, surface water, drainage basin, standard limit
\end{abstract}

\section{INTRODUCTION}

Water pollution in Nigeria occurs in both rural and urban areas. Many factories in Nigeria are located on river banks and use the rivers as open sewers for their effluents. The problems associated with the lack of adequate resources in the country threaten to place the health of about 40million people at risk (WHO/UNEP, 2004). The World Bank studies (World Bank, 1990) suggest that it would cost in excess of US $\$ 10,000000000$ a year to correct such problems if ground and surface water contamination goes unchecked.

Water contamination place other resources such as fisheries at risk and land resources, for example, have already been affected significantly. Most of the environmental pollution arise from anthropogenic sources, mainly from domestic and industrial activities (FEPA, 1991). Failure to halt further deterioration of environmental quality might jeopardize the health of a large proportion of the population, resulting in serious political and socio-economic implications (FEPA, 1991).

Kano, which is a closed-settled zone, with population density of 2.66 persons per hectare, is the largest city in northern Nigeria, serves as an important market for resources produced in the peri-urban zone. Kano metropolis is growing quickly. Statistics obtained from 2006 census suggests that Kano metropolis currently boast a population of just under 4million. Lewcock (1995) warns, contamination of water sources is a major threat, especially in the absence of adequate rainfall which might serve to dilute and flush out toxic elements. The Bompai-Jakara catchment basin is located within the city's three industrial estatesBompai, Challawa and Sharada- which according to the Ministry of Commerce and Industry had 44 food processing industries, 63 aluminium, metal and wood factories, 50 plastic rubber and tyre factories, and over 32 chemical and cosmetic industries (Bichi, 2000). All of these especially the tanneries and textile industries, use largest quantities of water and producing the greatest amounts of wastewater, that constitute the main sources of point pollution. A 1989 study, which monitored the activities of 15 tanneries in Kano, found that in all cases permissible limits for effluents discharge were violated (Binns et al., 2003). Osae-Addo (1992) opined that not only do downstream fish and vegetable crops become heavily contaminated with heavy metals, but human health is further threatened in urban and peri-urban Kano, because over 60 percent of local people depend on rivers and groundwater aquifers in the area for water. It is the aim of this work to assess $\mathrm{Fe}, \mathrm{Cu}, \mathrm{Cr}, \mathrm{Zn}$ and $\mathrm{Pb}$ concentrations in the surface water of BompaiJakara drainage basin, Kano state, northern Nigeria.

\section{MATERIALS AND METHODS}

\section{Study Area}

Kano is a city in northern Nigeria $\left(11^{0} 59.981 \mathrm{~N}, 008^{0}\right.$ 31.491E) (Figure 3.1) which is the largest city in northern Nigeria with the population density of 2.66 people per hectare (WHO/UNEP, 2004). The study area (Bompai and Jakara catchment basin) which is a dendritic type of drainage basin is a convergence of wastewater streams, of which Jakara River carries municipal waste from the Kano old city district, 
which runs northeasterly, while Getsi River carries industrial effluent from Bompai industrial estate, which runs northwesterly, and the confluence drains the wastewater into Wasai reservoir, located in the northeastern part of Kano metropolis, latitude $12^{\circ} 40^{\mathrm{I}}$ and $10^{0} 30^{\mathrm{I}} \mathrm{N}$, and longitude $7^{0} 40^{\mathrm{I}}$ and $9^{0} 30^{\mathrm{I}} \mathrm{E}$.

\section{Sampling Stations}

Six sampling stations were chosen for the study. Transect sampling cutting across the basin, starting from the two tributaries i.e. Jakara River and Getsi River; the confluence where the two rivers meet, the entry point where the water drains into the Wasai reservoir, the spillway and the outlet of the reservoir. The sampling was conducted from January to December of 2009 (12 month).

\section{Sampling Site A: Jakara River}

This is located on Jakara River, at Nomansland off Zungeru road $\left(11^{0} 58.822 \mathrm{~N}, 008^{0} 28.412 \mathrm{E}\right)$ in a high density residential area. Substantial vegetable production takes place on both banks of Jakara River, and crops are irrigated by water from the Jakara channel, which forms northern watershed of Kano, which flows through the Kano old city (Birni), specifically starting from Aminu Kano Way, Municipal, Gwale, Dala, Fagge, Sabon Gari and Gwagwarwa. The Jakara River serves as the main drain for built up areas along the way. Most of the wastewater entering the irrigation channel comes from residential sources (Figure 1).

\section{Sampling Site B: Getsi River}

This site is located $100 \mathrm{~m}$ away from Kwana Hudu Bridge on the River Getsi $\left(12^{0} 05.930 \mathrm{~N}, 008^{0} 37.807 \mathrm{E}\right)$. The river receives effluents from the Bompai industrial Estate. A significant proportion of the factories in operation at the industrial estate are tanneries and textile mills. Field observations revealed that PVC pipes are used underground for supplies of domestic potable water in the settlements surrounding Bompai which passes across the Getsi River (Figure 1).

\section{Sampling Site C: Magami (Confluence)}

The site is located within 5 meters away from the confluence of Jakara and Getsi rivers Getsi on $12^{0}$ $03.159 \mathrm{~N}, 008^{0} 32.689 \mathrm{E}$, where industrial effluents from the River Getsi and domestic wastewater from the Jakara River mix (Figure 1).

\section{Sampling Site D: Bela (Entry Point into Wasai reservoir)}

This site is the entry point (inlet) at which wastewater from the tributaries drain into the reservoir, located on $12^{0} 05.932 \mathrm{~N}, 008^{0} 37.806 \mathrm{E}$. It is an important fishing station and the banks are utilized for informal irrigation. The site is about $25 \mathrm{~m}$ away from the point where Jakara River drains into the Wasai reservoir.
The water, as the farmers called it bakin ruwa (black water), is dark grayish in colour as it enters the reservoirs, of which the colour fades after mixing with the reservoir water (Figure 1).

\section{Sampling Site E: Barwa (Spillway)}

This site is situated $5 \mathrm{~m}$ away from the spillway of the dam, located on $12^{0} 07.742 \mathrm{~N}, 008^{0} 41.235 \mathrm{E}$. It is an important fishing station; the banks are used for informal irrigation (Figure 1).

\section{Sampling Site F: Wasai (Outlet)}

This site is situated $5 \mathrm{~m}$ away from the regulated outlet of the dam, a fishing station and the banks are used for informal irrigation farming. Located on $12^{\circ}$ $08.766 \mathrm{~N}, 008^{0} 40.848 \mathrm{E}$ (Figure 1).

\section{Samples Digestion}

Water samples for heavy metals analysis were collected into $1 \mathrm{~L}$ bottles, with few drops of $\mathrm{HNO}_{3}$. Digestion was carried out using $\mathrm{HNO}_{3}$ acid method (APHA, 2005). The digests was diluted to $100 \mathrm{~cm}^{3}$ in volumetric flask and transferred into acid-washed plastic container, ready for analysis after labeling for analysis. The standard solutions (slightly acidic) were prepared in the range of $100 \mathrm{mgL}^{-1}$. The absorbance of the standard solutions (i.e. 2, 4, 6, 8, 10 $\mathrm{mgL}^{-1}$ ) were obtained. Cups $\left(5 \mathrm{~cm}^{3}\right)$ of the samples were aspirated one after the other without delay intermittently. Analysis was carried out using Atomic Absorption Spectrophotometer (AAS) in Central Laboratory of Bayero University, Kano for estimation of $\mathrm{Cu}, \mathrm{Fe}, \mathrm{Cr}$, $\mathrm{Zn}$ and $\mathrm{Pb}$ concentrations (APHA, 2005).

\section{Water Heavy Metals Analysis}

The concentrations of five heavy metals (i.e. $\mathrm{Pb}, \mathrm{Zn}$, $\mathrm{Fe}, \mathrm{Cr}$ and $\mathrm{Cu}$ ) was determined using Atomic Absorption Spectrophotometer (AAS) IL251 model. The instrument was set up at wavelengths specific to each element to be analyzed. Distilled de-ionized water aspiration between each reading was conducted. Readings of the absorbance were obtained by observing the steady galvanometer reading in 1-2mins. Analysis for each sample was carried out in triplicate to get representative results. The concentration of the metals was calculated using the standard calibration plot.

\section{Statistical Analysis}

SPSS version 15.0 statistical software was utilized in the computation of data for statistical significance. The data obtained were analyzed for descriptive (i.e. mean, sum, standard deviation, and range), correlation analysis with Kendall' tau-b correlation analysis, analysis of variance (ANOVA) and testing goodness of fit with Chi-squared test in order to test for significance between variables observed. 


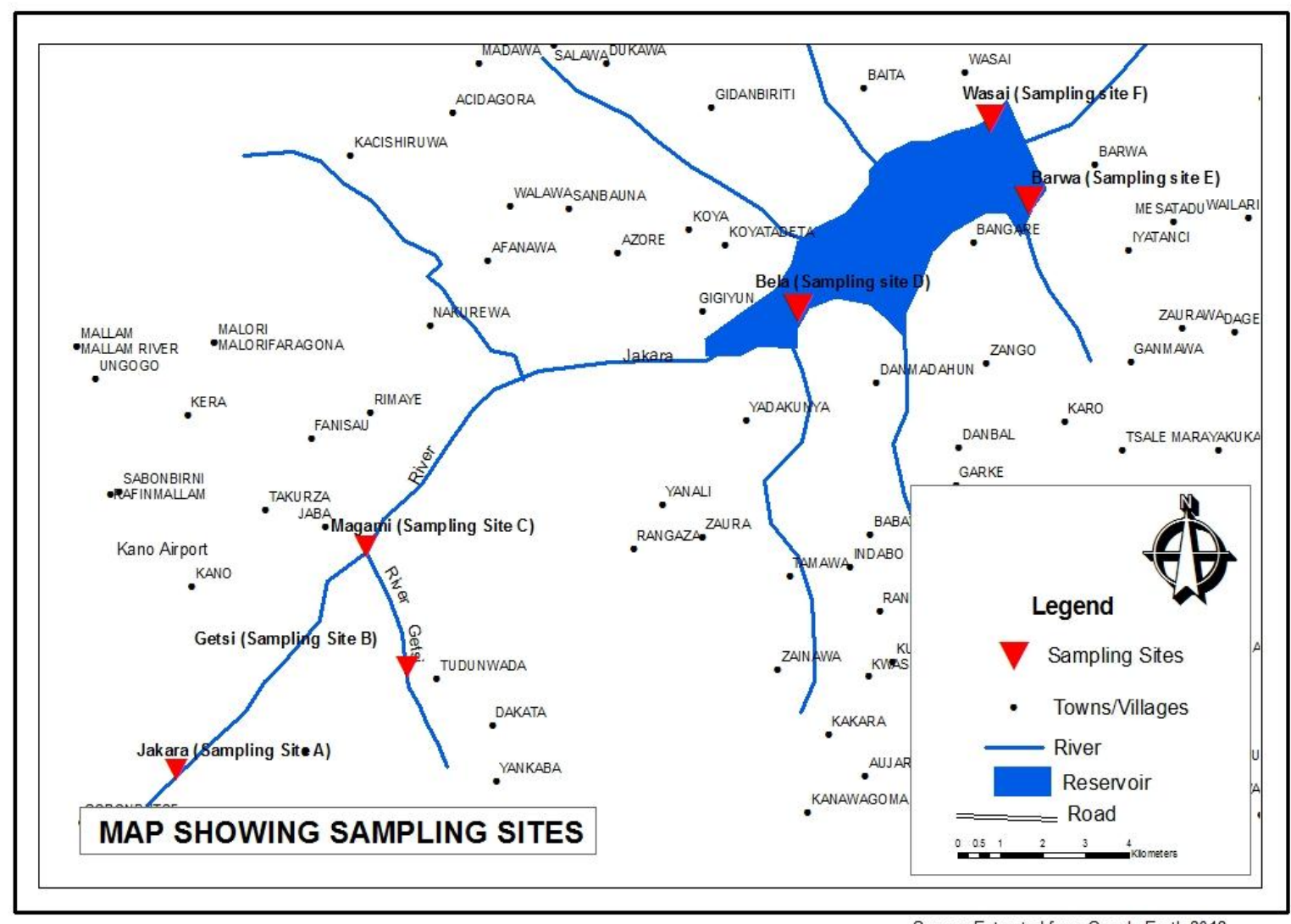

Source: Extracted from Google Earth 2012

Figure 1: Study Area: Bompai-Jakara Catchment Basin, Kano State, Nigeria and Sampling Sites (Source: Google Earth, 2008).

\section{RESULTS}

The result of this study showed the mean annual $\mathrm{Cr}$, $\mathrm{Pb}, \mathrm{Fe}, \mathrm{Cu}$ and $\mathrm{Zn}$ concentrations in surface water of Bompai-Jakara Catchment Basin, Kano State (Table 1), where $\mathrm{Cr}$ highest concentration of $12.33 \mathrm{mg} / \mathrm{L}$ was obtained at sampling site $\mathrm{F}$; Pb highest concentration of $7.00 \mathrm{mg} / \mathrm{L}$ was observed at site $\mathrm{E}$; Fe highest concentration of $12.58 \mathrm{mg} / \mathrm{L}$ was recorded at site $B$; $\mathrm{Cu}$ highest concentration of $11.00 \mathrm{mg} / \mathrm{L}$ was obtained at site $A$, and $\mathrm{Zn}$ highest concentration of $11.25 \mathrm{mg} / \mathrm{L}$ was observed at site $C$. Table 2 shows Kendall's tau-b correlation matrix between heavy metals in surface water of Bompai-Jakara catchment basin. There was significant positive correlation between $\mathrm{Cr}$ and $\mathrm{Fe}$ at $P \leq 0.05$. Figure 1 illustrates mean seasonal heavy metals concentrations of surface water in the BompaiJakara catchment basin, Kano State in 2009. Dry season shows higher concentrations of $\mathrm{Cr}, \mathrm{Fe}, \mathrm{Cu}, \mathrm{Zn}$ and $\mathrm{Pb}$ than the wet season through the year. The seasonal sequence of heavy metals concentrations showed $\mathrm{Zn}>\mathrm{Fe}>\mathrm{Cr}>\mathrm{Cu}>\mathrm{Pb}$ and $\mathrm{Fe}>\mathrm{Zn}>\mathrm{Cr}>\mathrm{Cu}>\mathrm{Pb}$ in dry and wet seasons respectively, while that of annual was $\mathrm{Cr}>\mathrm{Fe}>\mathrm{Zn}>\mathrm{Cu}>\mathrm{Pb}$.

\section{DISCUSSION}

$\mathrm{Cr}$ concentrations observed in the current study were above the maximum acceptable limit stated by FEPA (1991), WHO (1999), Lenntech (2008), Kaul and
Gautam (2002) and CCME (1995) of $<1.0 \mathrm{mg} / \mathrm{L}$, $0.05 \mathrm{mg} / \mathrm{L}, \quad 0.1 \mathrm{mg} / \mathrm{L}, \quad 2.0 \mathrm{mg} / \mathrm{L}, \quad$ and $0.002 \mathrm{mg} / \mathrm{L}$ respectively (Table 1 ). Exposure of aquatic organisms to $\mathrm{Cr}$ is through food and water, and it can cause renal and hepatic necrosis and growth depression. The range of $\mathrm{Cr}$ concentration obtained in this current study was higher that what was reported $(1.214 \mathrm{mg} / \mathrm{L})$ in the work of and Bala et al. (2008), but lower than that of Mustapha (2008a and b) of $1.0-496 \mathrm{mg} / \mathrm{L}$ conducted both in Jakara-Getsi river system. Reasons could be deduced based on the period of sampling, and frequency of sampling which could lead to discrepancies in values obtained.

$\mathrm{Pb}$ concentrations recorded in this study were above the maximum acceptable limits stated by FEPA (1991) of $<1.0 \mathrm{mg} / \mathrm{L}$, likewise were above the CCME (1995) limit for ecosystem protection of $0.07 \mathrm{mg} / \mathrm{L}$, above $1.0 \mathrm{mg} / \mathrm{L}$ which is Indian standard for industrial effluent into inland water (Kaul and Gautam, 2002). $\mathrm{Pb}$ is classified by USEPA as potentially hazardous to most forms of life and is considered toxic and relatively accessible to aquatic organisms. Low concentration of $\mathrm{Pb}$ affect fish by causing the formation of coagulated mucous over the gills and subsequently over the entire body and this may lead to death of fish due to suffocation. $\mathrm{Pb}$ is bioaccumulated by benthic macroinvertebrates and fish (Awofolu, 2005). 
Bajopas Volume 5 Number 1 June, 2012

Table 1: Mean Annual Total Heavy Metal Concentrations (mg/L) in Surface Water of Bompai-Jakara Catchment Basin (2009).

\begin{tabular}{|c|c|c|c|c|c|c|c|c|c|}
\hline Element & $\mathbf{A}$ & $\begin{array}{l}\text { Sampling Site } \\
\text { B }\end{array}$ & C & D & $\mathbf{E}$ & $\mathbf{F}$ & Mean \pm SD & $\begin{array}{l}\text { Range } \\
\text { Minimum }\end{array}$ & Maximum \\
\hline $\mathrm{Cr}$ & $12.00 \pm 3.521$ & $13.5 \pm 4.888$ & $11.67 \pm 4.215$ & $13.00 \pm 5.367$ & $11.17 \pm 4.215$ & $12.33 \pm 4.546$ & $12.3 \pm 0.847$ & 11.17 & 13.5 \\
\hline $\mathrm{Pb}$ & 6.67 & \pm 2.995 & & & & & $5.94 \pm 0.740$ & 5.33 & 7 \\
\hline $\mathrm{Fe}$ & $10.75 \pm 3.334$ & $12.58 \pm 4.166$ & $10.58 \pm 3.088$ & $11.17 \pm 3.664$ & \pm 3.490 & $11.08 \pm 4.889$ & $11.05 \pm 0.871$ & 10 & 12.58 \\
\hline $\mathrm{Cu}$ & $11.00 \pm 8.421$ & $7.75 \pm 4.615$ & $9.08 \pm 6.735$ & $6.42 \pm 3.729$ & 3.279 & $7.17 \pm 4.261$ & $7.96 \pm 1.811$ & 6.25 & 11 \\
\hline $\mathrm{Zn}$ & $10.00 \pm 3.567$ & $11.08 \pm 4.461$ & $11.25 \pm 4.555$ & $11.5 \pm 5.231$ & $10.08 \pm 3.288$ & $10.75 \pm 4.224$ & $10.78 \pm 0.621$ & 10 & 11.5 \\
\hline
\end{tabular}

Table 2: Kendall's tau-B Corelation Matrix Between Heavy Metals in Surface Water of Bompai-Jakara Catchment Basin, 2009.

\begin{tabular}{lccccc}
\hline $\begin{array}{l}\text { Kendall's } \\
\text { tau_b }\end{array}$ & $\mathbf{C r}$ & $\mathbf{P b}$ & $\mathbf{F e}$ & $\mathbf{C u}$ \\
\hline & $\mathrm{Cr}$ & 1 & & & \\
& $\mathrm{~Pb}$ & -0.552 & 1 & & \\
& $\mathrm{Fe}$ & $1.000^{* *}$ & -0.552 & 1 & \\
& $\mathrm{Cu}$ & 0.067 & -0.138 & 0.067 & 1 \\
$\mathrm{Zn}$ & 0.333 & -0.138 & 0.333 & -.067 \\
\hline
\end{tabular}

*. Correlation is significant at the 0.05 level (2-tailed). ${ }^{* *}$. Correlation is significant at the 0.01 level (2-tailed).

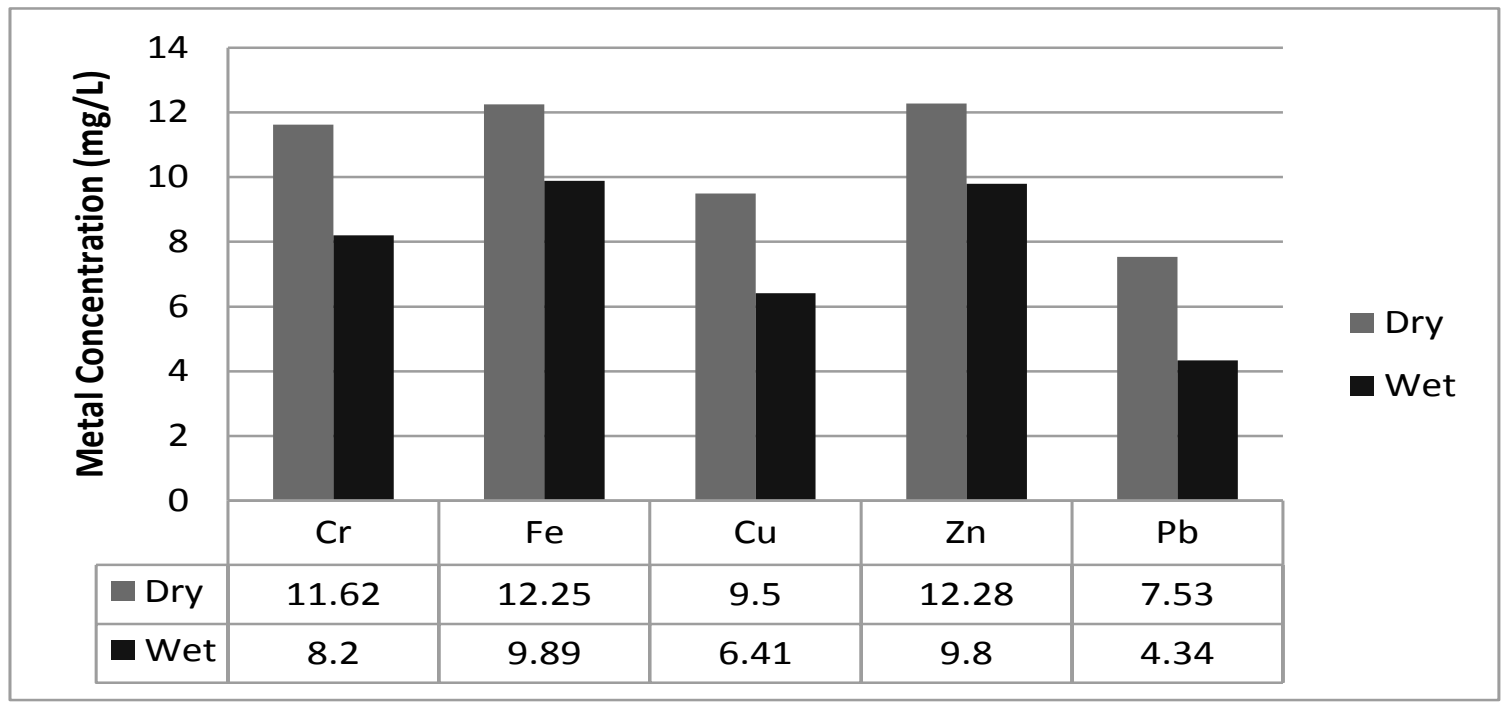

Figure 1: Mean Seasonal Heavy Metals Concentrations $(\mathrm{mg} / \mathrm{L})$ in surface water of Bompai-Jakara Catchment Basin, Kano State in 2009. 
$\mathrm{Pb}$ concentrations in the current study were higher than $1.25-2.84 \mathrm{mg} / \mathrm{L}, 0.345 \mathrm{mg} / \mathrm{L}$ and $0.01-0.18 \mathrm{mg} / \mathrm{L}$ reported by Ibrahim and Abdullahi (2008), Bala et al. (2008), and Inuwa (2007) respectively, but lower than what were obtained in the works of Mustapha (2008a) and Awoyinka et al. (2008) with $360-400 \mathrm{mg} / \mathrm{L}$ and $0.0-30.36 \mathrm{mg} / \mathrm{L}$ respectively. While the work of Mustapha (2008a) was carried out in the Jakara-Getsi river system, that of Bala et al. (2008) and Inuwa (2007) were conducted in the Wasai reservoir, hence discrepancies could be gleaned from the difference in the sites of sampling, period and frequency of sampling.

Fe concentration obtained in the current study mostly fall within the FEPA (1991) standard acceptable limit of $20 \mathrm{mg} / \mathrm{L}$, but the result was above the Pescod (1992) and Lenntech (2008) of $5 \mathrm{mg} / \mathrm{L}$ as phytotoxic threshold for crop production (Table 1). Water containing $\mathrm{Fe}>2 \mathrm{mg} / \mathrm{L}$ causes staining of clothes (while washing) and sanitary wares and imparts bitter astringent taste (Maiti, 2004).

The range of Fe concentration observed in the current study is lower than $92.0 \mathrm{mg} / \mathrm{L}$ obtained in the work of Mustapha (2008a and b) conducted in the Jakara-Getsi river system, but was higher than $1.54 \mathrm{mg} / \mathrm{L}$ and $0.0 \mathrm{mg} / \mathrm{L}$ reported by Bala et al. (2008), and Emeka and Weltime (2008) respectively. This result indicated a worrisome trend of pollution by sources such as the industrial effluents and domestic waste.

The result of $\mathrm{Cu}$ concentration in the current study showed a very high level of contamination in both the Jakara-Getsi river system and Wasai reservoir (Table 1). The observed $\mathrm{Cu}$ values were above the maximum acceptable limit reported by WHO (1999), AWWA (1985), Lenntech (2008), Kaul and Gautam (2002) and CCME (1995) of $0.0 \mathrm{mg} / \mathrm{L}, 0.2 \mathrm{mg} / \mathrm{L}, 0.2 \mathrm{mg} / \mathrm{L}$, $3.0 \mathrm{mg} / \mathrm{L}$, and $0.004 \mathrm{mg} / \mathrm{L}$ respectively (Table 1 ).

The high $\mathrm{Cu}$ concentrations recorded in all the sites in the Bompai-Jakara catchment basin could be due to release from factories that make or use $\mathrm{Cu}$ compounds in the Bompai industrial estate. $\mathrm{Cu}$ could also enter the basin through waste dumping, domestic wastewater, combustion of fossil fuels and waste, wood production, phosphate fertilizer production, and natural sources (e.g. wind blown dust from native soils etc.). Aquatic organisms exposed to $\mathrm{Cu}$ through drinking the water or skin contact can have gastro enteric disorder especially in fish and other larger organisms. High oral intake of $\mathrm{Cu}$ in humans can cause liver and kidney damage and even death. The $\mathrm{Cu}$ concentration obtained in the current study were higher than that reported by Bala et al. (2008) in the Getsi River of $0.453 \mathrm{mg} / \mathrm{L}$, likewise, were considerably higher than what was observed in the work of Emeka

\section{REFERENCES}

APHA (2005): Standard Methods for the Examination of Water and Wastewater. $21^{\text {st }}$ edition, eds. Eaton, A.D., Clescer, L.S., Rice, E.W. and and Weltime (2008) of $0.0001 \mathrm{mg} / \mathrm{L}$ conducted in Damaturu water works. Explanation to these discrepancies could be due to the period of sampling, frequency and source of water or wastewater under study.

The $\mathrm{Zn}$ concentrations observed in this study revealed a generally higher values (Table 1 ) compared with the maximum acceptable limit stated by FEPA (1991), WHO (1999), AWWA (1985), and Kaul and Gautam (2002) of $5.0 \mathrm{mg} / \mathrm{L}$, as well as that of CCME (1995) of $0.03 \mathrm{mg} / \mathrm{L}$. Exposure to highest concentration of $\mathrm{Zn}$ through ingestion of food material and/or water leads to nausea, abdominal cramp, diarrhea etc in humans exposed to high concentration. Dermal exposure to $\mathrm{Zn}$ compound can result in severe skin iiritancy, characterized by parakeratosis, hyperkeratosis, inflammatory changes in the epidermis and superficial dermatitis etc (ATSDR, 2008).

$\mathrm{Zn}$ concentrations recorded in the current study were higher than $0.25 \mathrm{mg} / \mathrm{L}, 0.0 \mathrm{mg} / \mathrm{L}, 0.37 \mathrm{mg} / \mathrm{L}$ and $2.0 \mathrm{mg} / \mathrm{L}$ obtained in the works of Bala et al. (2008), Emeka and Weltime (2008), Awoyinka et al. (2008), and Inuwa (2007) respectively. This shows worrying trend in increase of unchecked pollution of the catchment basin without any hinderance by the factories, or improper dumping of domestic waste by the dwellers along the basin.

Figure 1 shows seasonal variations; in which dry season had relatively higher heavy metals concentrations than the wet season, although not statistically significant at $P \leq 0.05$. This variation could be due to higher evapotranspiration that occurred in the dry season without other input into the drainage basin through rainfall (Bichi, 2000; Binns et al., 2003). There was significant correlation between $\mathrm{Cr}$ and $\mathrm{Fe}$ concentrations at $\mathrm{P} \leq 0.01$.

Correlation was shown to be significant between $\mathrm{Cr}$ and Fe concentrations; this could be due to their close proximity between the two elements as transition metals sharing similar electron orbital structures and hence similar chemical properties. $\mathrm{Cr}$ can replace part of the Fe. They can also combine either as compound, solutions or simply as intimate mixtures (Gaul, 2008).

\section{CONCLUSION AND RECOMMENDATIONS}

This study may highlight the implications of releasing effluent without treatment into the Bompai-Jakara drainage basin, which reveals a worrying trend of high levels of heavy metals that are mostly toxic to aquatic fauna and flora and humans at large. It is important for the government concerned to establish water catchment management agency which will see to it that no harm enters into the basin, and appropriate penalties should be enforced on the defaulters.

Greenberg, A.E. Port City Press, Baltimore, MA, US.

ATSDR (2008): Minimal Risk Level. Agency for Toxic Substances and Disease Registry. www.atsdr.cdc.gov. accessed on 01/12/2008. 
Awofolu, O.R. (2005): A Survey of Trace Metals in Vegetation, Soil and Lower Animals along Some Sellected Major Roads in Metropolitan City of Lagos. Environmentaal Monitoring and Assessment. 105: 431-447.

Awoyinka, O.A., Ogunnowo, A.A., Olayanju, F.O. and Adeniran, O.A. (2008): Biological Safety Evaluation of Sediment and Surface Water of Ibu River in Sagamu, Ogun State, Nigeria. BEST Journal. 5(3): 126-129.

AWWA (1985): Standard methods for Examination of Wastewater, American Water Works Association, NY, USA.

Bala, M., Shehu, R.A. and Lawal, M. (2008): Determination of the Level of some Heavy Metals in Water Collected from Two Pollution-prone Irrigation areas around Kano Metropolis. BAJOPAS. 1 (1): 36-38.

Bichi, M.H. (2000): Surface Water Quality in the Kano Industrial Environment. In: Falola, J., Afolabi, K., Ahmed, M.A., Liman, A. and Maiwada, A. (eds) Issues in Land Administration and Development in Northern Nigeria. Dept. of Geography, Bayero University, Kano. Pp: 305-313.

Binns, T., Maconachie, R.A. and Tanko, I.A. (2003): Water, Land and Health in Urban and Periurban Food Production: The Case of Kano, Nigeria. Land Degradation \& Development. 14 (5): 431-444.

CCME (1995): Canadian Water Quality Guidelines for Protection of Freshwater Aquatic Life. Canadian Council of Ministers of the Environment. UNEP/CHM.7/8/Add.3.

EMA (2008): Guidelines on the Specification Limits for Residues of Metal Catalyst or Metal Reagents. Committee for Medicinal Products for Human Use, European Medicines Agency, Doc Ref. EMEA/CHMP/SWP/4446/2000.

Emeka, D.O. and Weltime, O.M. (2008): Trace Elements Determination in Municipal Water Supply in Damaturu Metroplis, Yobe State, Nigeria, BAJOPAS, 1(1): 58-61.

FEPA (1991): National Environmental Protection (Effluent Limitation) Regulations of 1991. Federal Environmental Protection Agency, Lagos, Nigeria. Ref. S.1-8.

Gaul, P.L. (2008): Metals In: Microsoft Encarta, Microsoft Corporation, Redmond, WA.

Ibrahim, S. and Abdullahi, B.A. (2008): Effect of Pb on Zooplankton Dynamics in Challawa River, Kano State, Nigeria, BAJOPAS, 1(1): 88-94.

Imam, T.S. (2011): Some Aspects of Ecology and Biomonitoring of Heavy Metals Associated with Industrial Pollution in the Bompai-Jakara Catchment Basin, Kano State, Nigeria. A PhD Final Seminar held at Department of Biological Sciences, Bayero University, Kano (Unpublished). 23 $3^{\text {rd }}$, Mar. 2011.

Inuwa, B. (2007): Studies on Aspects of Physicochemical Conditions and the Fish Biology in Jakara Dam, Kano, Nigeria. A M.Sc. Thesis Submitted to the Biological Sciences Department, Bayero University, Kano (Unpublished).

Kaul, S.N. and Gautam, A. (2002): Water and Wastewater Analysis. Daya Publishing House, Delhi, India. Pp: 3-250.

Lenntech (2008): Water Treatment. Published by Lenntech. Rotterdam, Netherlands. www.excelwater.com/thp/filters/waterpurifica tion.htm

Lewcock, C. (1995): Farmer Use of Urban Waste in kano. Habitat International. 19 (2): 225-234.

Maiti, S.K. (2004): Handbook of Methods in Environmental Studies: Water and Wastewater Analysis.Vol. I, ABD Publisher, Jaipur, India. Pp: 242-266.

Mustapha, A. (2008a): An Assessment of the Suitability of Water in Jakara-Getsi River system for Fadama Production at the Kano Region, Kano State. Techno Science Journal. 1 (1): 118-124.

Mustapha, A. (2008b): Environmental Pollution in Kano: The Contribution of Wastewater Discharge from Kano Old City and Bompai Industrial Estate to Jakara River Basin System. Techno Science Journal. 2 (1): 8388.

Osae-Addo, A. (1992): Nigeria: Industrial Pollution Control. Sector Report Draft. (cited in World Bank, 1995:5).

Pescod, M.B. (1992): Wastewater Treatment and Use in Agriculture. FAO Irigation and Drainage Paper, 47, Food and Agriculture Organization, UN, Rome, IT.

WHO (1999): Limits for Effluents Discharge into Surface Waters. World Health Organization, Geneva, $\mathrm{CH}$.

WHO/UNEP (2004): Water Pollution Control-A Guide to the Use of Water Quality Management Principles. Eds. Helmer, R. and Hespanhol, I. United Nations Environment Program, the Water Supply and Sanitation. Collaborative Council and the World Health Organization.

World Bank (1990): Towards the Development of an Envronmental Plan for Nigeria. Report No. 9002-UNI. World Bank, Washington, DC. 